\begin{tabular}{|l|l|l||}
\hline \multicolumn{2}{|c|}{ PublisherInfo } \\
\hline \hline PublisherName & $:$ & BioMed Central \\
\hline \hline PublisherLocation & $:$ & London \\
\hline \hline PublisherImprintName & $:$ & BioMed Central \\
\hline \hline
\end{tabular}

\title{
Sweet success
}

\begin{tabular}{|l|l|l||}
\hline \multicolumn{2}{|c|}{ ArticleInfo } \\
\hline \hline ArticleID & $:$ & 4061 \\
\hline \hline ArticleDOI & $:$ & $10.1186 /$ gb-spotlight-20010423-04 \\
\hline \hline ArticleCitationID & $:$ & spotlight-20010423-04 \\
\hline \hline ArticleSequenceNumber & $:$ & 132 \\
\hline \hline ArticleCategory & $:$ & Research news \\
\hline \hline ArticleFirstPage & $:$ & 1 \\
\hline \hline ArticleLastPage & $:$ & 2 \\
\hline \hline & & RegistrationDate : 2001-04-23 \\
ArticleHistory & $:$ & OnlineDate \\
\hline \hline ArticleCopyright & $:$ & BioMed Central Ltd2001 \\
\hline \hline ArticleGrants & $:$ & \\
\hline \hline ArticleContext & $:$ & 130592211 \\
\hline \hline
\end{tabular}




\section{Jonathan B Weitzman}

Email: jonathanweitzman@hotmail.com

Receptors on the surface of the tongue's specialized taste bud cells allow us to distinguish the five classes of tastes: sweet, sour, bitter, salty and unami. Receptors responding to bitter tastes are members of the G-protein-coupled receptor (GPCR) family, but mammalian sweet receptors have not been found. Two papers, published in the May issues of Nature Genetics and Nature Neuroscience, report the cloning of a candidate taste receptor gene, T1r3, which is linked to the Saclocus that determines mouse sensitivity to sweet tastants. Both groups scoured the human genomic sequence around chromosome 1p36, syntenic to the Sac locus on the distal end of mouse chromosome 4, in search of GPCR genes. They identified one gene that encodes a receptor with seven transmembrane helices and a large extracellular domain, and is similar to T1R1 and T1R2, two 'orphan' GPCRs (with no known ligands) that are expressed on taste cells. T1R3 is specifically expressed on a subset of taste cells in mouse taste buds. Montmayeur et al. characterized six amino acid changes that differed between mice which can taste saccharin and non-tasters, and found a perfect correlation between T1r3 alleles and Sac phenotypes in recombinant inbred strains (Nature Neuroscience 2001, 4:492-498). Max et al. suggest that the nontaster polymorphism may affect protein glycosylation and interfere with receptor dimerization (Nature Genetics 2001, 28:58-63). Montmayeur et al. found that T1R3 expression overlapped with that of the related receptor T1R2, and proposed that the two may form heterodimers. Max et al. note that it is fitting that a glycosylation event should determine sensitivity to sweetness and predict that these results will help identify novel sweeteners.

\section{References}

1. Cellular mechanisms of taste transduction.

2. T2Rs function as bitter taste receptors.

3. Nature Genetics, [http://genetics.nature.com]

4. Nature Neuroscience, [http://neurosci.nature.com]

5. High-resolution genetic mapping of the saccharin preference locus (Sac) and the putative sweet taste receptor (T1R1) gene (Gpr70) to mouse distal Chromosome 4.

6. Putative mammalian taste receptors: a class of taste-specific GPCRs with distinct topographic selectivity.

This PDF file was created after publication. 